\title{
Disability discrimination in insurance
}

\author{
Birgit Kuschke \\ $B L C L L D$ \\ Associate Professor, University of Pretoria
}

\section{OPSOMMING \\ Gestremdheidsdiskriminasie in versekering}

Diskriminasie in die finansiële sektore soos versekering word nie alledaags onder die loep geneem nie. Die een industrie waarin daar daagliks teen persone gediskrimineer word, is versekering. Versekeringsmaatskappye groepeer versekerdes in verskillende risikogroepe volgens hulle risikoprofiele. Die omvang van risiko word meestal volgens die groep se algemene of gemiddelde kenmerke bereken. Versekerdes wat nie noodwendigerwys dieselfde risiko as ander lede van die groep inhou nie, word hierdeur benadeel deurdat hulle hoër premies betaal of verminderde dekking of voordele geniet. Die optrede deur die versekeraar stel prys-, transaksie- en statistiese diskriminasie daar. Dikwels oorvleuel die gronde vir 'n bepaalde groepering met verbode gronde van diskriminasie soos onder andere in die Grondwet uiteengesit. Faktore wat die meeste ter sprake kom, is gestremdheid, ouderdom, en geslag. Die ongeregverdigde diskriminasie affekteer die versekerde se regte op gelykheid en waardigheid.

Vanweë die ontelbare vorme en grade van gestremdheid, is dit uiteraard vir versekeraars moeilik om voldoende inligting in te win en om volgens elke aansoeker se unieke persoonlike omstandighede 'n billike toedeling te maak. Aan die ander kant, moet alle versekerdes ook dieselfde behandel word, en uitsonderings kan verswarend op ander lede van die groep inwerk. Hierdie probleem regverdig egter geensins onbillike diskriminasie nie.

Die probleem lê daarin dat daar onsekerheid heers oor wat wel geregverdigde diskriminasie of differensiasie daarstel. Versekering speel 'n belangrike rol in ons samelewing, en verswarende verpligtinge om dekking, premies en bedinge van geval tot geval aan te pas kan die versekeringsbedryf se winsgewendheid bedreig. Ander lande probeer die probleem deur teikengerigte versekeringswetgewing bestuur. Dit is egter nie die geval in Suid-Afrika nie, en kan 'n beroep op die wetgewer gedoen word om oorweging daaraan te skenk om 'n groter mate van regsekerheid in die voorgestelde nuwe versekeringswetgewing te skep, deur gevalle wat as direkte onbillike diskriminasie geag word, te identifiseer. Die voorstel is dat voorskrifte in ondergeskikte wetgewing soos Polishouerbeskermingsreëls ingebou word, ten einde vinniger aanpassings en wysigings wat met mediese en tegnologiese vordering wat gestremde persone se risikoprofiele verbeter, tred hou. 


\section{Introduction}

The idea of human rights in essence is a belief in the existence of a form of justice that is universally valid for all people. All sectors, public as well as private, are bound by the human rights to equality and nondiscrimination. ${ }^{1}$ The right not to be discriminated against due to a disability is addressed in the United Nations Convention on the Rights of Persons with Disabilities (hereafter the 'Convention'). ${ }^{2}$ The discussion below deals with issues raised in the Convention specifically in the context of insurance discrimination.

Discrimination in a social or socio-economic context has been part of the daily narrative. ${ }^{3}$ Discrimination in a purely economic sense, such as in the financial sector, however has not enjoyed as much attention. ${ }^{4}$ Discrimination is mostly regulated within the health, welfare and employment frameworks.

1 Fagan Internet Encyclopaedia of Philosophy, available at www.iep.utm.edu (accessed 2014-08-29). Recognised as a 'privatisation of human rights', as described by Clapham 'Human Rights in the private sphere' Oxford Monographs in International Law (1993) 289.

2 UN General Assembly 25 Aug 2006, signed and ratified by South Africa in 2007.

3 Discrimination is also mostly regulated within the health, welfare and employment frameworks. South Africa has no comprehensive disability legislation as is the case in other countries. See notes 4, 41-46 below. For the national position see also he Integrated National Disability Strategy White Paper issued by the Office of the President [date unknown], available at www.independentliving.org (accessed 2015-08-09).

4 Reported cases on discrimination in insurance include Christian Roberts and Others $v$ Minister of Social Development Case No 32838/05 (heard in September 2007, judgment handed down only in 2010) (TPD) which dealt with age and gender discrimination between men and women for social disability grants; Satchwell v President of the Republic of South Africa 2002 (6) SA 1 (CC) that dealt with discrimination of same-sex partners in claiming pension and retirement benefits; Brink v Kitshoff NO 1996 (4) 197 (CC): discrimination against married women of certain benefits of life insurance policies; Minister of Finance $v$ Van Heerden 2004 (6) SA 121 (CC): differentiated employer contributions to a pension fund based on employment; As stated, no case law has been reported on disability discrimination in insurance. The striking lack of jurisprudence is also reiterated by Webster in 'Contract Law and Human Rights' in Reid and Visser Private law and Human Rights Bringing Rights Home in Scotland and South Africa (2014) UCT Press 294. Only a few pages are dedicated to the issue in most of the authoritative South African constitutional law works. Authoritative case law is limited to IMATU v City of Cape Town 2005 (10) BCLR 1084 (LC) heard in the labour court on disability in the context of the Employment Equity Act; and Master of the High Court $v$ Deedat and others 1991 (11) BCLR 1285 (N) where a trustee was removed from office after suffering stroke. The court held in the latter case that this was due to lack of capacity, and not discrimination. Discrimination on the basis of disability insurance was not at issue in these two cases. 
Insurance is the industry in which people are dealt with in a discriminatory manner the most on a daily basis. ${ }^{5}$ In a foremost case heard on discrimination in the insurance industry, the Supreme Court of Canada recognised in Zurich Insurance Company $v$ Ontario, Zurich Insurance Co $v$ Ontario Human Rights Commission ${ }^{6}$ that '[a] fundamental tension between human rights law and insurance practice exists.' South African case law on insurance discrimination is scant, as cases often settle out of court. ${ }^{7}$ To date no case law has been reported in our courts on disability discrimination in insurance.

Insurance companies in fact are in the business of discrimination when they segregate insureds into different risk groups or pools based on their risk profiles. Insurance companies are unable to price risks that they cannot analyse, assess or quantify, a practice which necessitates some form of arbitrary grouping or classification. Sometimes the act of classification coincides with discrimination on a prohibited or unjustified ground, such as race, gender, sex, pregnancy, marital status, ethnic or social origin, colour, sexual orientation, age, disability, religion, conscience, belief, culture, language and birth. ${ }^{8}$ Such discriminatory conduct potentially infringes on the fundamental right to dignity. ${ }^{9}$

The degree of risk inevitably is determined on the basis of a specific group's common or general characteristics which are material to the risk. Some insureds placed in a group do not necessarily share the average characteristics of that group, with the result that the rate they pay or the

5 Information presented in this publication was gleaned from Kuschke International Report on Discrimination in Insurance presented at the AIDA XIVth World Congress (International Association for Insurance Law World Congress) in Rome, Italy on 4 October 2014. The report provided information on the current general trends in discrimination by insurers against policyholders in the insurance industry. Twenty-eight countries who participated in the study were Argentina, Australia, Belgium, Brazil, Chile, Colombia, Costa Rica, Denmark, Finland, France, Greece, Hong Kong, Hungary, Israel, Italy, Japan, Mexico, New Zealand, Poland, Portugal, Republic of China: Taiwan, Republic of Korea, South Africa, Spain, Switzerland, Turkey, Great Britain and Uruguay. Some remarks are made in this article to illustrate some of the points made, but the purpose is not to present a comprehensive comparative study.

$61992(2)$ S.C.R. 321

7 See n4 above.

8 Section 9, Constitution of the Republic of South Africa, 1996. As the Constitution enjoys an indirect horizontal application in the relationship between individuals [s 8(2)], it impacts upon the contractual relationships between all role players in the insurance industry. Equality and nondiscrimination are also the focal points of the Promotion of Equality and Prevention of Unfair Discrimination Act 4 of 2000 that binds the state and all persons, including juristic, non-juristic and even a group or category of persons.

9 The right to dignity is recognised as a foundational value in $\mathrm{s} 10$ of the Constitution. See in general pars 5-5 to 5-9 in Cheadle, Davis \& Haysom South African Constitutional Law: The Bill of Rights (Issue 18 May 2015). The Convention Art 2(h) recognises also that discrimination against any person on the basis of disability is a violation of the inherent dignity and worth of the human person. 
extent of the insurance cover is discriminatory. ${ }^{10}$ The Convention recognises the diversity of persons with disabilities, which makes groupings difficult. ${ }^{11}$

Discrimination in insurance most often is based on age, gender and disability. ${ }^{12}$ Disabled or elderly persons seem mutely to accept a generalised grouping, often unaware that such a classification can be challenged and that standard-form or adhesion insurance contracts are not cast in stone and may be amended. ${ }^{13}$ The Convention stresses the importance of accessibility to information and communication, in enabling persons with disabilities to fully enjoy all human rights and fundamental freedoms. ${ }^{14}$ Finally, to add insult to injury, disabled persons might be discriminated against in the context of insurance on more than one factor. ${ }^{15}$

10 The diversity of disabilities and degrees of disability complicate matters, Persons with Down syndrome serve as an example. The life expectancy of a person with Down's syndrome can be relatively short, yet some survive well into middle age. Persons diagnosed with autism and persons suffering from other genetic abnormalities can fall within a broad spectrum. Some may be fully functional provided they are on medication or receive specialised treatment often at great cost, yet others not. Some may suffer from multiple forms of disability all of which impact on their grouping.

11 Art 2(i). Cover for persons diagnosed with HIV/AIDS is addressed by statutory regulation in most countries, and is not included in this discussion as one cannot equate disability with disease. It is thus not a 'disability' in the true sense. In Hoffmann v South African Airways 2000 (11) BCLR 1211 (CC) the court declined to comment on whether an HIV infection can be regarded as a 'disability' and protected as such under the Constitution s 9(3).

12 See in general the responses and data submitted by National Chapters of members of AIDA as reflected in the International Report on Discrimination in Insurance. The Employment Equity Act s 1 defines people with disabilities as "people who have a long-term or recurring physical or mental impairment, which substantially limits their prospects of entry into or advancement in, employment.'

13 Webster in Reid \& Visser Private Law and Human Rights: Bringing Home Rights in Scotland and South Africa 313 confirms that the problem is that 'courts, for example in Barkhuizen are willing to presume that (in the absence to the contrary), a standard form contract was as much a genuine exercise of freedom of contract as an individually negotiated one: Many persons are unaware that they may negotiate deviations from the printed contract form presented to them during contractual negotiations and accept that it is a take it or leave it' scenario. According to Cheadle, Davis and Haysom 4-40(2) disability discrimination usually arises from omissions or failures to act. In the context of insurance the insurer knowingly classifies persons with disabilities into broad groupings, and could fail to differentiate on personal degrees and refined characteristics of disability. The insurer could furthermore fail to inform potential policyholders of exclusions from cover, or other alternatives available in the market.

14 Article 2(v).

15 The Convention Article 2(p) confirms this point by recognising "the difficult conditions faced by persons with disabilities who are subject to multiple or aggravated forms of discrimination on the basis of race, colour, sex, language, religion, political or other opinion, national, ethnic, indigenous or social origin, property, birth, age or other status.' 
Inequality potentially affects the validity of a contractual clause, as it may be contrary to public policy to enforce an agreement that was entered into while the person laboured under the inequality. ${ }^{16}$ The South African Supreme Court of Appeal, since the judgment in Barkhuizen $v$ Napier, has accepted that there can be 'a constitutionally-inspired public policy challenge to the enforcement of a prima facie reasonable contractual term'. ${ }^{17}$ On the other hand one should always keep in mind that contractual autonomy to voluntarily consent to a specific categorisation and cover is a part of the rights to freedom and to dignity. ${ }^{18}$

It is a common understanding that insurers should be able to differentiate, but that not all types of discriminatory differentiation by insurers should be tolerated. The issue is how to identify acceptable grounds for differentiation and what are the limits for legitimate economic discrimination. The discussion below aims to comment on some of the issues pertaining specifically to the insurability of persons with mental or physical disabilities, but does not attempt to provide a comprehensive analysis.

\section{Nature of insurance discrimination}

The United Nations Human Rights Committee states: 'The term discrimination should be understood to imply any distinction, exclusion, restriction or preference which is based on any ground[s] and which has the purpose of nullifying or impairing the recognition, enjoyment or exercise by all persons, on an equal footing, of all rights and freedoms., 19 The UN Convention on the Rights of Persons with Disabilities (hereinafter the 'Convention') ${ }^{20}$ that was signed and ratified by South Africa in 2007 describes 'discrimination on the basis of disability' as meaning 'any distinction, exclusion or restriction on the basis of disability which has the purpose or effect of impairing or nullifying the recognition, enjoyment or exercise, on an equal basis with others, of all human rights and fundamental freedoms in the political, economic, social, cultural, civil or any other field'. ${ }^{21}$

Discrimination in the insurance industry clearly falls within these broad descriptions, yet mostly is justified as a form of personalisation of

16 Constitution s 172(1)(a) that a particular term or contract is unenforceable if incompatible with the Constitution.

17 Reid and Visser supra n1 3 306. Ngcobo J in Barkhuizen found the public policy approach to be correct; dissenting judgments by Sachs J, Moseneke J and Mokgoro $\mathrm{J}$ also confirmed this principle.

18 Cameron J in Brisley v Drotsky 2002 (4) SA 1 (SCA) par 94.

19 UN Human Rights Committee General Comment 18: Non-discrimination (1989). Two important constitutional issues that arise in this context are the inequality of bargaining power and outright discrimination. This article attempts to address only the latter.

20 UN General Assembly 25 Aug 2006.

21 Art 2: Definitions. 
the insurance product. This claim allows insurers to maintain financially sound underwriting policies, to bring competitive offers to the market and it enables insurers to charge different premiums for the different risk profiles. Preventing poor market performance within an essential sector of the economy and promoting business efficiency and profitability and, on the other hand, acting fairly towards all insurance consumers when underwriting, poses a challenge for the industry. Insurers should take cognisance of the fact that their conduct may be unconstitutional and may affect the policies they issue. ${ }^{22}$

In order to maintain equity among insured persons, clearly each policyholder should be charged a premium rate proportional to the actual risk he or she transfers to the insurance fund. ${ }^{23}$ If one person is allowed to pay less than his or her proportional share to prevent discrimination, necessarily this will lead to an overcharge against other persons, again creating inequality and a type of reverse discrimination. ${ }^{24}$

In insurance discrimination usually is based on universal generalisations such as the physical and physiological health status of the individual, but not on individual traits. Broad classifications include temporary, permanent, partial or recurring disabilities. A cause for concern has been raised in the case of the so-called 'marginal cases': where persons are merely temporarily lacking in the criteria required for proper risk differentiation. This definition applies especially to some mental disabilities. Examples include individuals who in the past have been diagnosed as suffering from epilepsy, dementia and schizophrenia, yet, who upon full recuperation, fail to procure sufficient cover due to their past medical history.

Discrimination in insurance is seen primarily as a form of price discrimination where higher rates are charged for minorities, or as deal discrimination where some minorities do not qualify for or are not offered the same extent of services or goods. The access offered to disabled persons to personal injury or medical insurance cover serves as an example. ${ }^{25}$

Discrimination in insurance furthermore is a form of statistical discrimination, based on a theory of stereotyping. Inequality and the preferential treatment of some persons can be classified as statistical

22 See the Convention that specifically recognises the need in Art 8 on Awareness-raising.

23 As concluded by Nienaber and Van der Nest: 'Actuarial science versus equity: Contingency deductions for future loss of earnings and the HIV/ AIDS pandemic' 2005 THRHR 546.

24 Note must however be taken of the Convention Article 5 on Equality and non-discrimination that '[s]pecific measures which are necessary to accelerate or achieve de facto equality of persons with disabilities shall not be considered discrimination under the terms of the present Convention.'

25 Price discrimination occurs when a product is sold at different prices for different classes of buyers. In most cases in insurance the different premiums charged are not related to the differences in the cost of providing the underlying cover. 
discrimination because stereotyping may be based on the average behaviour of a specific risk group. ${ }^{26}$ Theoretically, an insurer is inclined to substitute group averages in the absence of direct information about a certain fact, characteristic or ability. This factor causes the unfair discrimination of atypical individuals from a disadvantaged group. One cautions that not all categorisations or groupings necessarily lead to prejudice, a consequence which renders them incontestable. ${ }^{27}$

Statistical discrimination often is applied and tolerated, for example when older people are charged more for life insurance, when people with a medical history are charged more for health insurance and when disabled drivers, who are quite capable of driving a vehicle safely and competently with adapted controls, are charged more for car insurance.

The modern insurance consumer's intolerance of discrimination in insurance became clear in the Test Achats case ${ }^{28}$ in the EU where gender distinction in the calculation of motor insurance premiums was held to be discriminatory. This ruling truly put the cat amongst the pigeons. Many countries allowed insurance companies to charge men and women with identical driving records different rates or to factor in gender when deciding whether to deny coverage. Although an attempt to attain optimal equality, the judgment in this case violates the primary insurance principle that risk must be calculated by taking all relevant information into account, and that one cannot treat all persons and all risks equally. ${ }^{29}$

26 This theory was pioneered by Arrow 'The Theory of Discrimination', in Ashenfelter and Rees (eds) Discrimination in Labor Markets (1973); Phelps 'The Statistical Theory of Racism and Sexism' 1972 American Economic Review 659.

27 Thomas 'Non-Risk Price Discrimination in Insurance: Market Outcomes and Public Policy' (2012) The Geneva Papers of The International Association for the Study of Insurance Economics 1018-5895/12 37 explains that one type of price discrimination, called 'inertia pricing' is not necessarily prejudicial. This occurs where renewal prices are higher than prices for riskequivalent new customers. Although this practice appears to intensify competition, leading to lower aggregate industry profits, policyholders in aggregate pay lower prices. On the other hand not all customers are better off and some end up paying a disproportionate amount. The high level of switching cover between insurers to avoid this problem however is found to be inefficient for society as a whole. One should recognise the basic principle that groupings do not necessarily introduce bias.

28 Association belge des Consommateurs Test-Achats ASBL, Vann van Vugt, Charles Basselier $v$ Conseil des ministres C 236/09 heard in the European Court of Justice, hereinafter the 'Test Achats' case. The applicants brought the case to the ECJ for a preliminary ruling under Art 234 EC from the Cour constitutionelle (Belgium) in 2011, pertaining to the effect of The European Union's Gender Directive, Art 5(2) of the Council Directive 2004/113/EC of 13 Dec 2004 on the differentiation of motor insurance premiums based on gender. See in this regard the case discussion by Kuschke 'Association belge des Consommateurs Test-Achats ASBL, Vann van Vugt, Charles Basselier v Conseil des ministers: Gender Equality in insurance' De Jure 2012624.

29 The threat that unfair discrimination holds in attaining the goal of equality in fact goes beyond the individual or the personal affront of the claimant. Albertyn and Goldblatt 'Facing the challenge of transformation: difficulties 
Rather than using general factors the insurer should assess the risk of the individual insured, applying appropriate and neutral rating variables suited to the particular circumstances and attributes as well as to the behaviour of the individual seeking insurance. This practice would require a much more intensive risk evaluation and literally would require the insurer to create bespoke insurance cover for each applicant. It is submitted that such an approach theoretically gives effect to the right to equality, but is not necessarily practically feasible.

Although insurers must be allowed to complete realistic risk assessments, they should respect principles of transparency, antidiscrimination, proportionality and good customer policy, such as Treating Customers Fairly or 'TCF'. 30 Discrimination should be avoided unless it is justified by a legitimate aim, and if the means of achieving it are appropriate and necessary demonstrating a reasonable proportion between the differentiated treatment and the aim pursued. ${ }^{31}$ Rather than outright exclusion, various techniques can be applied to personalise the insurance product and discriminate to a lesser degree. These techniques include premium adjustments, selection of benefits, deductibles or the provision of or recommendation to procure alternative cover.

\section{Equality in South African insurance practice and legislation}

After the UN Convention on the rights of Persons with Disabilities (hereafter the 'Convention') ${ }^{32}$ was signed and ratified by South Africa in $2007^{33}$ only national laws needed to be developed in accordance with the Convention. There is no separate statute that deals in general with the rights of disabled persons.

As supreme law in our country the right to equality as set out in section 9 of the Constitution renders discrimination on one or more of the listed

in the development of an indigenous jurisprudence of equality' 1998 SAJHR 248 272-3 recognise that the need goes beyond mere formal equality and mere non-discrimination which requires identical treatment, whatever the starting point or impact.

30 TCF principles are introduced in South Africa by the "Financial Services Board "Treating Customers Fairly Framework": Annexure B' on fairness in service or product delivery, and will apply for instance where a customer may not have been treated fairly, for example if sold a product such as a policy on which they subsequently may be unable to claim.

31 For a discussion on the fact that our courts have watered down 'the proper approach' in applying constitutional values in decisions pertaining to the unconstitutionality of contracts, see Woolman 'The amazing vanishing Bill of Rights' 2007 SALJ $762772-779$.

32 UN General Assembly 25 Aug 2006.

33 Effectively recalling the previous International Covenant on Economic, Social and Cultural Rights. 
grounds unfair unless its fairness is established. ${ }^{34}$ In order to prove that the discrimination is fair, one must take into account whether it reasonably and justifiably differentiates between persons according to objectively determinable criteria that are intrinsic to the activity concerned. ${ }^{35}$ The following aspects need to be taken into consideration: ${ }^{36}$ (a) whether the discrimination impairs or is likely to impair human dignity; (b) the impact or likely impact of the discrimination on the complainant; (c) the position of the complainant in society and whether he or she suffers from patterns of disadvantage or belongs to a group that suffers from such patterns of disadvantage; (d) the nature and extent of the discrimination; (e) whether the discrimination is systemic in nature; (f) whether the discrimination has a legitimate purpose; (g) whether and to what extent the discrimination achieves its purpose; (h) whether there are less restrictive and less disadvantageous means to achieve the purpose; (i) whether and to what extent the respondent has taken such steps as being reasonable in the circumstances (i) to address the disadvantage which arises from or is related to one or more of the prohibited grounds or (ii) to accommodate diversity.

Discriminating factors that apply specifically to insurance products and services provided to persons with disabilities are identified as: (a) unfairly refusing on one or more of the prohibited grounds to provide or to make available an insurance policy to any person; (b) unfair discrimination in the provision of benefits, facilities and services related to insurance; and (c) unfairly disadvantaging a person or persons. ${ }^{37}$ These are generalised provisions that provide no clear guidelines to the industry and insurance applicants so as to attain legal certainty as to the extent to which categorisation is found acceptable.

Within the last decade Kok recognised that these statutory provisions are insufficient to address the problems facing discrimination in insurance, and has urged that legislative reform is required in this regard. $^{38}$ Internationally the drive to introduce more specific insurance legislation to address this insufficiency proves this point. These developments will need to be in accordance with article 4 of the

34 The Constitution s 9(2) provides for the achievement of full and equal enjoyment of all rights and freedoms by authorising legislative and other measures designed to protect or advance persons or categories of persons disadvantaged by unfair discrimination. The Promotion of Equality and Prevention of Unfair Discrimination Act 4 of 2000 (hereinafter the 'Equality Act') gives effect to the Constitution to prevent or limit unjustified discrimination; s 6 of the Equality Act contains a general prohibition on unfair discrimination.

35 Idem at s14.

36 Idem at $\mathrm{s} 14(2)(\mathrm{b})$.

37 Idem Part 5 Schedule of the Act.

38 Kok A 'The Promotion of Equality and Prevention of Unfair Discrimination Act 4 of 2000: Proposals for Legislative Reform', 2008 South African Journal of Human Rights 445. 
Convention, promoting non-discriminatory legislation. ${ }^{39}$ Furthermore, they will be in line with the Constitution s 9(2) that provides for the achievement of full and equal enjoyment of all rights and freedoms by authorising legislative and other measures designed to protect or advance persons or categories of persons disadvantaged by unfair discrimination. In anticipation of the introduction of new insurance laws, initially proposed in 2014 to replace current insurance legislation, ${ }^{40}$ this goal might be achieved in the near future. ${ }^{41}$ Whether one should include detailed provisions on disability in financial markets and insurance in a separate disability act or whether the inclusion of some provisions in specific insurance legislation will prove to be more effective requires further analysis.

\section{Some thoughts on the position in other countries}

This report does not intend to provide a comprehensive discussion of legislation in any of the foreign jurisdictions. The purpose of this brief exposition is purely to indicate that discrimination in insurance enjoys attention universally and to provide some guidance as to future development in South African laws.

Most countries have introduced general anti-discrimination laws, yet few have laws that specifically target discrimination in insurance underwriting. Examples of the few countries that have legislation that applies exclusively to disability law and that includes specific sections on

39 Convention Art 4 General obligations: 1. States Parties undertake to ensure and promote the full realization of all human rights and fundamental freedoms for all persons with disabilities without discrimination of any kind on the basis of disability. To this end, States Parties undertake: (a) To adopt all appropriate legislative, administrative and other measures for the implementation of the rights recognized in the present Convention; $(b)$ To take all appropriate measures, including legislation, to modify or abolish existing laws, regulations, customs and practices that constitute discrimination against persons with disabilities; and $(e)$ To take all appropriate measures to eliminate discrimination on the basis of disability by any person, organization or private enterprise;

40 In accordance with the National Treasury Policy Document 23 February 2011. Acts that are in the firing line include the Long-Term Insurance Act 52 of 1998 and Short-term Insurance Act 53 of 1998.

41 The three-way test as explained by the court in the Van Heerden case par 37 to prevent the legislation from being contested as unconstitutional will have to be kept in mind. The first question would be whether any measure targets persons or a category of persons from a previously disadvantaged group. The second, whether it is designed to protect and advance the interests of those persons previously disadvantaged, and in the third instance, whether the statutory measure in fact promotes the achievement of equality. 
discrimination in insurance include Australia; ${ }^{42}$ Hong Kong; ${ }^{43}$ Israel; $^{44}$ Mexico $^{45}$ and Spain. ${ }^{46}$

Many countries have laws that apply to financial services in general (which mostly includes insurance) ${ }^{47}$ or general consumer laws (which might include insurance) that address the issue of insurance discrimination. In South Africa insurance legislation is silent on the issue. Insurance has also been excluded from the scope of the South African Consumer Protection Act, thus removing it from the protection created for disabled persons in our general statutory consumer law. ${ }^{48}$

Some countries address the issue in separate insurance statutes or Codes of Conduct that apply within the insurance industry. The following are excellent examples that relate to disability insurance discrimination.

The Hong Kong Motor Vehicles Insurance (Third Party Risks) Ordinance provides that policies ab initio are void if they restrict coverage due to discriminatory factors such as age, and the physical or mental condition of the driver. ${ }^{49}$ The Hong Kong Equal Opportunities Commission 'Discussion Paper on Insurance Issues under Antidiscrimination Legislation' and 'Statement of Best Practice on Disability Discrimination' issued by the Hong Kong Federation of Insurers attempt to comprehensively regulate insurance discrimination, including disability discrimination.

Japan has enacted The Insurance Business Act ${ }^{50}$ which provides that policy conditions and premiums may not be unfair or discriminatory, and The Law Concerning Non-Life Insurance Rating Organisation ${ }^{51}$ that provides that all rates shall be reasonable, adequate and not unfairly discriminatory. The Spanish Insurance $\mathrm{Act}^{52}$ expressly prohibits discrimination based on disability. ${ }^{53}$

The Association of British Insurers Good Practice Guide ${ }^{54}$ on the Equality Act 2010 provides that insurers must be aware of and meet equality obligations. The Equality and Human Rights Commission Codes of

42 Disability Discrimination Act 1992.

43 Disability Discrimination Ordinance (Cap 487).

44 The Equal Rights for People with Disabilities, 1998.

45 General Law for the Inclusion of Persons with Disabilities 2013.

46 General Act on the rights of persons with disability and their social inclusion (2013).

47 For an example of a country with advanced specialised laws, see the Danish Law on Equal Treatment between Men and Women in connection with Insurance, Pension and Financial Services.

48 Act 68 of 2008; exempted by the promulgation of the Financial Services Laws General Amendment Act 45 of 2013

49 Chap 272 of 30/06/1997.

50 Law No. 105 of June 7, 1995 art 4(1) and 4(2).

51 Law No 193, updated by Law No 160 art 8.

52 Act 50/1980.

53 4th AP.

54 The Guide for Consumers, and Guide for the Insurance industry of Association of British Insurers (ABI) 
Practice $^{55}$ prescribes equality duties for financial service providers that specifically including the rights of persons with disabilities. A nonstatutory agreement between government and the British Insurance Brokers Association promotes transparency and upon refusal/exclusion from cover brokers must refer the unsuccessful applicants to another service/product or supplier that can meet their risks. This requirement meets the universal duty to inform prospective policyholders and raise awareness.

An interesting aspect in respect of the onerous duties on insurers in Portugal can be found in the Portuguese Insurance Institute Regulation, which established conditions for insurers obtaining and applying actuarial and statistical data to in fact guarantee that the risk categorisation is justified, proportionate and non-discriminatory. ${ }^{56}$ Failure to comply where the categorisation does prove to be discriminatory is a breach of statutory duty and a breach of warranty towards the insurance consumer.

These statutes and prescriptions in many respects tend to differ in substance and in the nature and scale of regulatory enforcement across most lines of insurance and policyholder characteristics. This situation becomes clear from the different positions that apply in the EU. In the USA there is no federal law specifically forbidding insurers from taking into account discriminatory factors when issuing insurance policies, although individual State's laws might differ. ${ }^{57}$

When attempting to introduce new anti-discrimination laws cognisance may be taken of the experience and lessons learned in foreign jurisdictions when addressing the issue.

\section{Conclusion}

For the purposes of this discussion, it would be more prudent to refer to differentiation rather than discrimination. Not all differentiation necessarily is discrimination. ${ }^{58}$ It is impossible not to take person-related factors into consideration when assessing insurance risks. Individual characteristics must be considered without being classified outright as discriminatory per se.

Discriminatory practice is justified and should be allowed where it is based on reasonable grounds, independently assessed and relying on a true distinction or differentiation.

55 Of 6 April 2011.

56 Notice 8/2008-R.

57 See with regards to the different positions in the various states of the USA Avraham, Logue, and Schwarcz 'Understanding Insurance Anti-Discrimination Laws' (2013) Law\& Economics Working Papers Paper.52, available at http://repository.law.umich.edu/lawecon (accessed 2015-03-02).

58 The Convention in Art 2(e) recognises that disability remains an evolving concept. 
One should keep in mind that the right to equality in fact does not prohibit discrimination but rather unfair discrimination. When determining whether discrimination is fair or not, one should evaluate the impact of the discriminatory treatment on the victim, and also weigh the importance of the limitation against the proportionality of the infringement. Discrimination from the outset is assumed or deemed to be unfair unless it is established to be fair in accordance with specific statutory criteria. This assumption places some burden on insurers to prove fairness.

The underwriting process is concerned primarily with significant risk exposures that are not common to all persons seeking insurance. What is important is that risks in each grouping or classification must be as homogenous as possible to ensure the necessary balance and equality among policyholders accepted into each classification. This requirement could prove to be challenging where disabilities are concerned as the circumstances of individuals differ greatly. Yet this fact should not detract from the important statement by Sachs J in Minister of Home Affairs $v$ Fourie that " $[\mathrm{t}] \mathrm{o}$ penalize people for who and what they are is profoundly disrespectful'. 59

One can support the position that the insurance business should not follow a blanket discriminatory practice, but rather should approach insurance applications by persons with unique circumstances on a caseby-case basis. The nature of the disability on its own should not be the determining factor, but, in conjunction with statistical and actuarial and other empirical data, should be applied consciously for risk selection and classification in insurance underwriting.

The mere absence of statistics is not enough to prove irrefutably that there is no alternative to the discriminatory practice. ${ }^{60}$ Difficulty alone in providing statistical or actuarial information is an unacceptable excuse for discriminatory conduct in a commercial relationship that infringes on a disabled person's fundamental rights. ${ }^{61}$ The White Paper on the Integrated National Disability Strategy recognises that South Africa has a discriminatory and weak legislative framework which has sanctioned

592006 (3) BCLR 355 CC par 60.

60 The Integrated National Disability Strategy recognises the following: 'There is a serious lack of reliable information on the nature and prevalence of disability in South Africa. This is because, in the past, disability issues were viewed chiefly within a health and welfare framework. This led naturally to a failure to integrate disability into mainstream government statistical processes. Statistics are unreliable for the following reasons: (a) there are different definitions of disability; (b) different survey technologies are used to collect information; (c) there are negative traditional attitudes towards people with disabilities; (d) there is a poor service infrastructure for people with disabilities in underdeveloped areas, and (e) violence levels (in particular areas at particular times) have impeded the collection of data, affecting the overall picture'. See also the Convention Art 21 that recognises a disabled person's right of access to information.

61 Zurich Insurance Co v Ontario Human Rights Commission par 23. 
and reinforced exclusionary barriers. As a result large sections of the legislative framework in South Africa fail to meet international human rights standards and principles with regard to the rights of people with disabilities. ${ }^{62}$

Furthermore, factors and differentiation methods must be applied equally and consistently to all applicants. Given the wide application of the equality clause it is clear that a possibility of a constitutional argument presents itself where a party to a contract can identify an area where he is treated differently from someone in an analogous position.

On the other hand, due to the valuable social service insurance provides the solvency and profitability of insurance companies should be protected. In South Africa, the Long-term Insurance Act confirms that it is the statutory duty of insurance companies to keep their policies actuarially sound, which implies that insurers are not bound to issue life insurance cover to any insurance applicant, yet they are bound by the universal and constitutional principle of non-discrimination. As classification of risks and the setting of premiums are the essence of insurance business, insurance companies are more likely to prosper and the interests of all their policyholders are more likely to be protected and promoted if insurers are permitted to differentiate. They should be entitled to classify risks and fix premiums in accordance with their own sound judgment, provided that they are founded upon actuarial data and prudent insurance practice. Insurers should be sensitive to the fact that these practices might result in an unfair discrimination. On the other hand, insurance applicants and policyholders also carry a duty to inform themselves of their position and of alternative coverage available when negotiating policy premiums and terms of cover.

In order to provide support to insurers the answers to these difficulties might be found in a more specified framework or guidance notes on classifications and groupings. Legislation must be easily adaptable to remain relevant and keep abreast of medical and technological advances that can positively affect the risk profile of persons with disabilities. Therefore, inclusion in subordinate legislation, such as the insurance Policyholder Protection Rules, that may be adopted without lengthy parliamentary process can be recommended.

Even though industry supervision and regulation could curb improper practices, the position in other countries has shown that a comprehensive legislated solution is not easily attainable. As an argument against restrictive legislation, McQueen confirms an emphasis on the understanding that " $[\mathrm{t}$ ] he law [i.e. contract law] is founded on ideas of transactional equality, private autonomy, and voluntary

62 The White Paper states: '[a]lthough there has, since 1994, been some attempt to identify and eliminate discriminatory legislation from our statute books, many aspects of past discriminatory legislation still remain. In addition, some new laws and amendments contain sections which directly or indirectly lead to discrimination against people with disabilities.' 
interaction, in which, within very broad limits, individuals strike their own balance of interests, rather than have it set for them by external, social or public standards'. ${ }^{63}$ On the other hand, Woolman reiterates the following viewpoint in response to the judgment in Barkhuizen: 'I work within a tradition of constitutional law - of which South Africa is most avowedly a part - that recognizes rules as a necessary feature of the legal landscape'. ${ }^{4}$

In view of even the Constitutional Court failing to generate cognizable legal rules and meaningful legal precedent, statutory intervention might be the answer to provide greater certainty, accuracy and legitimacy in respect of differentiated treatment. Furthermore, the Constitution section 8(3) sees legislation as its 'first port of call' in giving effect to human rights, whereas common law development is relied on only where legislation is absent or deficient. ${ }^{65}$ In the absence of South African statutory law, foreign law can offer guidance to our legislator and our courts in developing anti-discrimination laws. ${ }^{66}$

63 MacQueen 'Delict, Contracts and the Bill of Rights: A Perspective from the United Kingdom’ 2004 SALJ 359376.

64 Woolman 791

65 Reid and Visser supra n13 at 349.

66 Idem at 351. 